Piwulang 8(2)(2020)
Teaching
http://journal.unnes.ac.id/sju/index.php/piwulang

\title{
CITRA PEREMPUAN JAWA DALAM TEKS SULUK TENUN
}

\author{
Andriyana Fatmawati ${ }^{1}$ dan Nur Hanifah Insani ${ }^{2}$ \\ ${ }^{1}$ Universitas Islam Negeri Sunan Kalijaga \\ ${ }^{2}$ Universitas Negeri Semarang \\ Corresponding Author: andriyana.fatmawati@uin-suka.ac.id
}

DOI: $10.15294 /$ piwulang.v8i2.42686

Accepted: November $17^{\text {th }} 2020$. Approved: December $14^{\text {th }} 2020$. Published: December $18^{\text {th }} 2020$

\begin{abstract}
Abstrak
Suluk Tenun mencerminkan citra perempuan Jawa yang didasari latar tradisi agama Islam. Ditinjau dari pendekatan feminisme budaya penelitian ini menggunakan metode deskriptif kualitatif dan filologi modern, bertujuan untuk mendeskripsikan citra perempuan Jawa yang tercantum dalam teks Suluk Tenun. Sumber data yang digunakan dalam penelitian ini adalah teks Suluk Tenun Koleksi Perpustakaan Pura Pakualaman, terletak pada pupuh VII Serat Piwulang Estri, dan terdiri dari 17 bait. Hasil penelitian menunjukkan bahwa teks Suluk Tenun sarat dengan nilainilai moral dan budaya Jawa. Adapun simbol alat dan proses menenun digunakan untuk menggambarkan citra perempuan Jawa dalam mengendalikan hawa nafsu ketika berumah tangga seperti telanjuk, kaki, kuping, kisi, dll. Dalam teks Suluk Tenun dijelaskan beberapa citra yang harus dimiliki oleh seorang perempuan agar mampu menjadi perempuan suci. Citra tersebut adalah perempuan harus berilmu, mampu mengendalikan hawa nafsu, dan mampu bersandar dengan iman kepada Tuhan serta syariat.
\end{abstract}

Kata Kunci: Suluk Tenun, Citra, Perempuan Jawa

\begin{abstract}
Suluk Tenun reflects the image of Javanese women based on the background of Islamic religious traditions. Judging from the cultural feminism approach, this research uses descriptive qualitative methods and modern philology, which aims to describe the image of Javanese women listed in the text of Suluk Tenun. The data source used in this research is the text Suluk Tenun, a collection of Pura Pakualaman Library, located at pupuh VII Serat Piwulang Estri, and consists of 17 verses. The results showed that the text of Suluk Tenun was loaded with Javanese moral and cultural values. The symbols for the tools and the weaving process are used to describe the image of Javanese women in controlling their passions when they are married, such as telanjuk, kaki, kuping, kisi, and others. In the Suluk Tenun text, several images must have by a woman to be able to become a holy woman. The images are women who must be knowledgeable, able to control their passions, and able to rely on faith in God and the shari'a.
\end{abstract}

Keywords: Suluk Tenun, images, Javanese Women

\author{
(C) 2020 Universitas Negeri Semarang \\ p-ISSN 2252-6307 \\ e-ISSN 2714-867X
}


Andriyana Fatmawati dan Nur Hanifah Insani/ Piwulang 8 (2) (2020)

\section{PENDAHULUAN}

Karya sastra suluk merupakan salah satu di antara karangan-karangan yang berisi ajaran keagamaan. Tujuan penciptaannya adalah sebagai media pendidikan dan pengajaran. Sastra suluk disampaikan menggunakan estetika bahasa yang khas yang ditandai dengan pemakaian simbol-simbol dan bentuk-bentuk alegori (Widyastuti, 2001:1). Istilah suluk dapat diartikan sebagai laku, tata cara, kewajiban yang harus dilakukan seseorang sebagai ahlus suluk. Karya sastra suluk merupakan jenis puisi Jawa yang berisi ajaran-ajaran yang bercorak sufistik atau mistik Islam. Karya sastra suluk diwarnai dengan tiga aspek yang dominan yakni aspek ketuhanan, aspek manusia dan aspek hubungan timbal balik antara Tuhan dan manusia (Purnama dalam Widyatuti, 2001: 2). Karya sastra suluk menempatkan manusia dalam kedudukan yang istimewa yaitu sebagai bayangbanyang Tuhan. Hal ini menjadikan manusia berpotensi sebagai insan kamil atau manusia sempurna melalui jalan laku.

Suluk Tenun merupakan salah satu karya sastra suluk yang terdapat dalam Serat Piwulang Estri. Serat Piwulang Estri ditulis dengan aksara dan bahasa Jawa pada tahun 1856 M. Serat Piwulang Estri merupakan naskah koleksi Perpustakaan Pura Pakualaman Yogyakarta dengan nomer kode 0060/PP/73. Suluk Tenun terletak pada pupuh VII Serat Piwulang Estri yang terdiri dari 17 bait berupa tembang macapat Asmaradana. Sebagai karya sastra suluk, Suluk Tenun didominasi oleh metafor-metafor yang berisi ajaran kehidupan bagi perempuan menggunakan simbol-simbol pertenunan baik alat, bahan maupun proses menenun. Suluk Tenun menggambarkan potret perempuan Jawa yang terdidik secara normatif sehingga lebih leluasa dalam menyesuaikan diri terhadap berbagai etika pada lingkungan sosialnya. Hal ini difungsikan dalam proses mendidik generasi penerus agar tercipta manusia yang cakap. Uraian dalam Suluk Tenun dimaknai sebagai citra perempuan untuk dapat mengendalikan hawa nafsu dalam menjalani hidup. Sama halnya seorang penenun yang harus cukup cermat dan sabar serta pikiran selalu iman pada Tuhan sebagai tujuan utama (Wulandari, 2016: 8).

$$
\text { Istilah citra perempuan }
$$
menggambarkan wujud mental spiritual dan tingkah laku keseharian seorang perempuan yang menunjukkan wajah dan ciri khasnya. Menurut Kamus Besar Bahasa Indonesia citra merupakan gambaran yang dimiliki orang banyak sebagai sebuah pribadi. Kepribadian seorang perempuan dapat dilihat melalui tindakan, ucapan, cara bergaul, cara berpakaian dan cara dalam menghadapi sebuah permasalahan. Pengertian tersebut menandakan adanya kaitan dengan penilaian masyarakat. Sedangkan Sugihastuti (2000: 43) mengungkapkan bahwa citra merupakan rupa dan gambaran yang dimiliki orang banyak mengenai pribadi, kesan mental, bayangan visual yang ditimbulkan oleh sebuah kata, frasa atau kalimat dan merupakan unsur dasar yang khas dalam karya prosa dan puisi. Citra perempuan dapat dibedakan menjadi dua yakni 
Andriyana Fatmawati dan Nur Hanifah Insani/ Piwulang 8 (2) (2020)

citra diri dan citra sosial. Citra diri terdiri dari aspek fisik dan psikis, sedangkan citra sosial terbagi menjadi dua yakni peran dalam keluarga dan peran dalam masyarakat.

Citra perempuan menurut pandangan hidup Jawa, secara fisik dan psikis merupakan makluk yang lemah jika dibandingkan dengan laki-laki, sehingga perlu adanya perlindungan melalui berbagai aturan-aturan tertentu. Sedangkan perempuan Jawa merupakan perempuan yang berbahasa Jawa dan cara berpikirnya berakar dari kebudayaan Jawa. Seorang perempuan dapat disebut perempuan Jawa jika dalam kesehariaanya mencerminkan perilaku kehidupan orang Jawa yakni menjunjung tinggi etika dan falsafah hidup. Perempuan (per-empu-an) sebagai empu atau induk dan puan atau tuan dianalogikan sempit menjadi perantara pengantar kehidupan sebagai pasangan laki-laki (Chalil, 1977: 11). Predikat kanca wingking merupakan hasil suatu kebudayaan yang dipengaruhi oleh sistem kolonial secara terus menerus, sehingga menjadikan perempuan terpingit. Selain itu, sisi lain perempuan Jawa sering kali dicap hanya untuk macak, manak, dan masak. Sigaraning nyawa atau garwa merupakan predikat lain yang melekat pada diri perempuan Jawa. Hal ini membuktikan bahwa perempuan Jawa tidak bisa terlepas dari peran laki-laki.

Suwarga nunut neraka katut merupakan sebuah ungkapan Jawa yang bermakna bahwa wanita akan selalu mengikuti dan melaksanakan apa yang diperintahkan suaminya. Ditinjau dari kehidupan pasca pernikahan, perempuan diciptakan untuk mengabdi dan berbakti kepada suami. Peran suami sebagai pemimpin keluarga sedangkan perempuan sebagai pengatur rumah tangga. Perempuan tidak hanya berperan sebagai istri tetapi juga sebagai ibu bagi anakanaknya. Berbagai peran tersebut harus dijalankan sekaligus, berlandaskan rasa cinta dan tanggung jawab. Dalam konvensi budaya Jawa perempuan mempunyai banyak sifat ideal, seperti menerima, pasrah, sabar, halus, setia, berbakti dan lainnya. Hal ini juga dipengaruhi oleh kultur budaya Jawa yang identik dengan bertutur kata halus, sopan santun, saling menghormati, cinta damai, menjunjung tinggi keharmonisan, kekeluargaan, gotong royong dan kerukunan.

Pandangan bahwa perempuan merupakan makhluk yang lemah dan tidak mempunyai kuasa tidaklah sepenuhnya tepat. Hal ini dibuktikan bahwa adanya tokoh-tokoh perempuan yang muncul sebagai prajurit wanita dengan berani dan terampil dalam berperang. Kumar dalam Wulandari (2016: 3) mengatakan bahwa perempuan Jawa dikenal dalam posisinya sebagai tentara wanita, bahkan disampaikan pula adanya sebuah kelompok Prajurit Wanita pada masa Mangkunegara I. Perempuan tampil di depan untuk menunjukkan kekuatannya dengan pakaian laki-laki , menunggang kuda, dan berlatih tata cara militer. Teks Nitipraja juga menggambarkan konsep kepemimpinan yang menyatakan bahwa posisi perempuan patut diperhitungkan. Perempuan dapat menempatkan diri sesuai porsi dan kodratnya sebagai perempuan yang baik bukan 
Andriyana Fatmawati dan Nur Hanifah Insani/ Piwulang 8 (2) (2020)

hanya sebagai perempuan yang ambisius sehingga menggorbankan segalanya (Wulandari, 2016: 3). Berbagai konsep tentang perempuan, meskipun sama-sama tumbuh di lingkungan budaya Jawa ternyata mengandung pro kontra. Disatu sisi perempuan dianggap makluk yang lemah dipihak yang lain menggangap perempuan adalah sosok yang kuat. Hal inilah yang menjadi daya menarik untuk menguak lebih dalam tentang kekuatan dan kelemahan perempuan dalam Suluk Tenun.

\section{METODE PENELITIAN}

Penelitian ini menggunakan metode deskriptif kualitatif, yaitu prosedur penelitian yang menghasilkan data deskriptif berupa kata-kata tertulis atau lisan dari orang-orang dan perilaku yang diamati (Widyastuti, 2014:116). Sumber data penelitian ini adalah teks Suluk Tenun dengan kode 0060/PP/73 koleksi Perpustakaan Pura Pakualaman. Selanjutnya penelitian ini, akan mendeskripsikan citra perempuan Jawa yang terdapat pada teks Suluk Tenun dengan menggunakan pendekatan feminisme budaya Jawa. Penelitian ini dibatasi pada deskripsi mencakup alat dan bahan tenun sebagai metafor citra perempuan Jawa.

Pengumpulan data dilakukan dari pembacaan naskah, transliterasi ortografi, parafrase dan terjemahan ke dalam bahasa Indonesia. Terjemahan teks menggunakan metode harfiah dan bebas. Tahap selanjutnya yakni pemaknaan dan penafsiran teks baik kata, frase, larik, maupun bait. Data-data yang relevan dengan tujuan penelitian dicatat dalam instrumen penelitian yaitu kartu data. Setelah ditemukan data berupa kata, kelompok kata, frase dan kalimat kemudian dianalisis menggunakan teknis analisis deskriptif kualitatif. Analisis data pada penelitian ini dibangun menjadi tiga ranah, yaitu tesa atau teori, antitesa atau data, dan sintesa atau analisis.

Masing-masing teori dan data kemudian dibangun seperti piramida terbalik. Deskripsi verbal ditafsirkan dengan memperhatikan konteks budaya Jawa. Validitas data menggunakan validitas simantis, yaitu memaknai data sesuai dengan kamus dan konteksnya. Konteks yang dimaksud adalah konteks cerita dan konteks mimetik karya tersebut. Reliabilitas data menggunakan teknik interater, yaitu dengan membaca berulang-ulang sehingga diperoleh data yang sama dan tidak berubah oleh peneliti secara mandiri.

\section{HASIL DAN PEMBAHASAN}

\section{a. Tenun dalam Masyarakat Jawa}

Tenun secara umum diartikan sebagai proses pembuatan kain dengan menyilangkan benang secara vertikal (lungsi) serta horizontal (pakan) dengan menggunakan alat tenun. Masyarakat Jawa mengenal kain tenun seperti masyarakat Nusantara lainnya yang disebut kain tenun lurik. Wahyono dalam Wuryani (2013: 84) mengatakan bahwa kata lurik seakar dengan kata dalam bahasa Jawa yaitu lorek yang berarti garisgaris atau lirik-lirik (bergaris kecil-kecil). Secara etimologi Jawa, bunyi “i” pada lurik menunjuk arti pada garis-garis kecil yang melintang dan membujur. Kain tenun lurik merupakan hasil 
Andriyana Fatmawati dan Nur Hanifah Insani/ Piwulang 8 (2) (2020)

budaya yang tidak akan lepas dari berbagai faktor yang menyertainya. Terdapat dinamika terhadap keberadaan tenun lurik dalam masyarakat Jawa baik dari aspek teknis, bentuk maupun fungsinya. Dilihat dari aspek fungsinya, kain tenun lurik saat ini telah terjadi pergeseran. Masyarakat Jawa menganggap kain tenun lurik bersifat profan dan magis serta memiliki nilai-nilai filosofi yang sarat dengan makna simbolik. Kain tenun lurik berkaitan erat dengan kepercayaan masyarakat Jawa seperti halnya upacara ritual keagamaan maupun adat. Filosofi dan makna simbolik sehelai lurik tercermin dalam motif dan warnanya. Corak tenun lurik yang beragam dianggap memiliki nilai sakral yang memberi tuah, dan ada pula yang mensiratkan nasehat, petunjuk, serta harapan.

\section{b. Citra Perempuan Jawa dalam Suluk Tenun}

Suluk Tenun merupakan salah satu bagian dari teks Piwulang Estri yang ditulis tahun 1756 tahun Jawa atau sekitar tahun 1834 M. Teks ini terdiri dari 17 bait tembang Asmaradana yang berisi ajaran-ajaran untuk perempuan. Piwulang diartikan sebagai ajaran sedangkan Estri dimaknai sebagai perempuan, secara menyeluruh naskah ini mengandung ajaran bagi kaum perempuan. Penyajian teks ini cukup unik karena menggunakan perumpamaan atau simbol-simbol sebagai ciri khas karya sastra suluk. Secara eksplisit teks ini menampilkan citra seorang perempuan dalam menjalani kehidupan berumah tangga. Suluk Tenun menggambarkan ajaran tentang perilaku perempuan yang suci. Dalam mencapai kesucian itu perempuan diwajibkan untuk menuntut ilmu dengan cara belajar agar mengetahui mana yang baik dan mana yang buruk. Selain itu, dengan belajar dan menguasai ilmu pengetahuan, perempuan akan terhindar dari kebodohan.

Selain itu, suluk ini mengajarkan agar seorang perempuan bersedia belajar untuk bersikap seolah-oleh mati dalam hidupnya, tidur saat terjaga, berhati-hati ketika bepergian, buta dapat menunjukkan jalan, bisu dapat meleraikan pertengkaran. Hal ini bertujuan agar seorang perempuan memahami hakikat asal-usulnya sebagai manusia. Seperti yang tercantum dalam kutipan di bawah ini.

Suluké pêrawan sukci / sinau mati jro gêsang / sinau turu yèn mêlèk / yitnané ngidêri paran / wuta nuduhkên marga / bisu bisa mêgot padu / suluk patênunan tamat // (VII, 17, a-g)

Terjemahan:

Suluknya perawan suci / belajar seolah mati dalam hidup / belajar tidur saat terjaga / berhati-hati ketika bepergian / buta dapat menunjukkan jalan / bisu dapat meleraikan pertengkaran / suluk pertenunan tamat // (VII, 17, a-g)

\section{1) Perempuan sebagai Ahli Tenun}

Perempuan diibaratkan sebagai ahli tenun mencirikan sifat perempuan yang penuh dengan ketelitian, kesabaran, dan ketekunan. Dalam proses menenun dibutuhkan waktu yang tidaklah sedikit dan proses yang rumit, sehingga 
Andriyana Fatmawati dan Nur Hanifah Insani/ Piwulang 8 (2) (2020)

perempuan dituntut mempunyai semangat untuk menyelesaikan serta mampu bertahan dalam sekian waktu. Tahapan-tahapan dalam menenun seperti halnya tahapan-tahapan seorang perempuan dalam mencapai kesucian jiwa. Diawali dari persiapan menenun dengan mempertimbangkan hari baik untuk memulai proses menenun. Penentuan hari ini menentukan seberapa jauh jiwa dalam menerima sebuah ajaran dan menjalankan tugasnya sebagai seorang perempuan yang baik.

Puniki suluké nênggih / padhang bulan kêkêncaran / sêdhêngé purnama sidyèng / kênya anglêmbur pakaryan / ngantih jéntranya anyar / sarwa anyar rahabipun / pasang rêgêp wus mirantya // (VII, 2, a-g) Panêmuné rara sukci / Sêntêg pisan katigasan / ing tanggal pisan wiwité / duk purnama sidènira / wayahé bakda salat / dintêné anuju Sêptu / wêktu pajar byar rahina // (VII, 16, a-g)

Terjemahan :

Inilah suluknya / terang bulan / ketika purnama / seorang perempuan bekerja lembur / dengan memintal benang dengan alat baru / semuanya baru / peralatannya sudah siap // (VII, 2, a-g) Pendapat perempuan suci / perkataan sekali jadi / diawali tanggal satu / ketika purnama / waktu selesai salat / menuju hari Sabtu / waktu fajar hingga terang // (VII, 16, a-g)
Tanggal satu awal bulan merupakan waktu yang sakral untuk memulai proses menenun. Pada malam bulan purnama seorang perempuan akan bekerja lembur untuk menyelesaikan tenunannya. Proses menenun ini akan diakhiri pada waktu fajar pada hari Sabtu setelah malam purnama usai.

Tanggal satu awal bulan merupakan tanggal dimana malam tanpa cahaya. Bulan tidak bersinar, gelap tanpa penerangan. Hal ini menggambarkan keadaan seorang perempuan yang belum berilmu. Aura yang gelap, tidak memancarkan kecerdasan, penuh dengan kebodohan, dan tidak mampu membedakan mana yang baik dan buruk. Hal ini menjadi petunjuk bahwa seorang perempuan harus mulai belajar menuntut ilmu agar selamat dunia dan akhirat. Tahap demi tahap seorang perempuan mencari jati diri tentunya akan menemui banyak hambatan seperti halnya orang yang menenun. Dengan memantapkan hati, menguatkan iman, dan ketulusan batin semata-mata hanya untuk beribadah kepada Tuhan menjadikan modal dasar untuk mencapai manusia yang suci. Seperti halnya bulan, awal bulan cahaya terasa gelap total kemudian berangsung-angsur ada titik terang, semburat bulan sabit memancarkan cahaya hingga menuju purnama yang terasa terang benderang. Tingkat kecerahan cahaya ini menyimbolkan tingkat kesucian perempuan. Ketika bulan purnama perempuan berada dititik paling sempurna dan akan mencapai keutuhannya ketika terbitnya fajar hingga siang. Keutuhan ini dicapai saat perempuan selesai dengan seluruh tugas-tugasnya yakni menenun 
Andriyana Fatmawati dan Nur Hanifah Insani/ Piwulang 8 (2) (2020)

artinya telah melalui segala hambatan dan berhasil memperoleh pencerahan jiwa.

\section{2) Perempuan, Alat Dan Bahan Tenun}

Proses menenun memerlukan waktu yang tidak sedikit dan alat dan bahan yang rumit. Sebelum proses menenun dimulai diawali dengan pengolahan benang lusi dan benang pakan terlebih dahulu sebagai bahan utama pembuatan kain tenun. Dalam teks Suluk Tenun bahan utama ini melambangkan keberadaan jiwa atau ruh seorang perempuan. Proses pengolahan benang lusi menurut Mulyanto (2018: 34) diawali dengan proses pewarnaan atau pencelupan, setelah itu benang digulung dalam kelos. Benang ditata menggunakan hani lalu digulung pada boom atau disebut pengebooman. Proses selanjutnya yaitu penyucukan yaitu memasukkan benang lusi pada mata boom dan sisir dan terakhir penyetelan. Sedangkan proses pengolahan benang pakan diawali dengan pengelosan yakni benang digulung pada kelos kemudian dilakukan pemidangan yaitu benang ditata dalam streng atau spanram. Dilanjutkan dengan pengikatan, benang pada spanram diikat menggunakan rafia sesuai dengan motif yang diinginkan. Setelah itu benang dicelupkan kedalam pewarna dan diwarnai dengan cara dikuas. Kemudian benang digulung dari streng ke kincir yang disebut proses pengiciran dan diakhiri dengan pemaletan atau menggulung benang dari kincir ke palet.

Teks Suluk Tenun menceritakan bahwa hal pertama yang dilakukan seorang perempuan dalam menenun adalah melakukan ngantih atau memintal benang yang akan ditenun pada kleting (gulungan benang yang dimasukkan dalam teropong). Ngantih merupakan proses pengolahan benang pakan yang pertama atau disebut pengelosan. Benang pada konteks ini merupakan ruh seorang perempuan. Pada bagian awal proses menenun ini, ruh disiapkan untuk menerima berbagai ajaran kebaikan dari Tuhan Yang Maha Esa. Dalam proses pembuatan benang, baik lusi maupun pakan, tentunya menggunakan berbagai alat tenun. Dalam teks Suluk Tenun alat-alat tenun diibaratkan sebagai sarana pengolahan jiwa sedangkan proses menenun diibaratkan cara pengolahan jiwa (Andrianie, 2004: 195). Berbagai alat tenun tersebut mengandung berbagai konsepsi budaya Jawa, diantaranya :

a) indhên, tali yang berfungsi seperti rantai pada motor dan merupakan alat pemutar roda pada alat pengantih yang tertarik tegang. Tali yang tertarik tegang melambangkan suatu keadaan dengan intensitas tindakan yang tinggi. Permulaan seorang wanita dalam menggapai kesucian dilandaskan dengan niat yang kuat, tidak mudah goyah dan mampu menyatukan seluruh rasa demi tercapainya ketenangan jiwa.

b) Têlanjuk, alat yang menancap pada kerangka alat pengantih. Selain niat kuat, iman yang kokohpun menjadi modal utama seorang perempuan dalam proses belajarnya. Iman merupakan pedoman dasar dalam pengasahan jiwa yang menancap dalam hati. Ketika seorang 
Andriyana Fatmawati dan Nur Hanifah Insani/ Piwulang 8 (2) (2020)

perempuan sudah mantap dengan segala resikonya maka proses memperoleh kesucian jiwapun akan lancar.

c) Kaki, alat untuk menggerakkan roda secara berkesinambungan. Kaki merupakan bagian tubuh manusia yang berfungsi sebagai alat gerak bawah sehingga menopang keseluruhan badan ketika berdiri, berjalan, ataupun berlari. Kaki menggerakkan roda, artinya seorang perempuan dalam meraih kesucian jiwa diharapkan mampu menyiapkan jiwa raganya agar terhubung dengan Yang Kuasa. Selain itu ia juga harus mampu menggerakkan jiwa raganya agar mempunyai ritme yang sama, artinya tujuan pencarian jati diri antara hati dan raganya sejalan, tidak saling bertolak belakang. Roda berbentuk lingkaran dan selalu berputar. Seorang perempuan dalam melangkah menuju kesucian jiwa tentunya berdasarkan tuntunan dari Yang Maha Kuasa. Setiap putaran roda diibaratkan sebuah doa, dengan tujuan memuji kebesaran Ilahi. Puji-pujian yang tiada putus, saling berkesinambungan selama menjalani hidup di dunia ini sehingga jiwa dan raga akan selaras.

d) Kuping, pengait besi berbentuk seperti telinga. Kuping atau telinga berfungsi sebagai alat pendengaran. Seorang perempuan dalam mengolah jiwa membutuhkan peran pendengaran dalam menangkap dan memahami suatu ajaran. e) Kisi, sejenis kayu kecil yang berfungsi sebagai tempat meletakkan klêting. Kisi melambangkan pusat penglihatan. Selain perlunya peran pendengaran dalam pengolahan jiwa, seorang perempuan membutuhkan peran panca indra yang lain yaitu penglihatan. Mata untuk melihat, diharapkan mampu membuka mata hati, bersifat terbuka dalam menerima ajaran, mau mengakui kesalahan, dan mau mengikuti ajaran.

f) Kêndhêng, tali tampar kecil yang tampak jelas. Keberadaan jiwa dilambangkan dengan benang / lawe yang terbuat dari kapas. Kapas ini dibelitkan pada sebuah penggilingan yang berbentuk cakra. Tali kecil (kêndhêng) ini membantu dalam membersihkan kapas dari kotoran. Kêndhêng dalam konteks ini dimaknai sebagai sarana untuk membersihkan jiwa dari segala keburukan. Jiwa yang sudah bersih kemudian perlu adanya sebuah penekanan, dengan tujuan supaya siap menerima suatu ajaran baru dan mampu menerapkan dalam kehidupan sehari-hari.

g) Pusuh, gulungan kapas yang telah dibersihkan untuk klêting untuk menghasilkan bennag yang lembut. Seorang perempuan setelah menerima ajaran hendaknya memilah dan menyesuaikan dengan kemampuan masing-masing. Membersihkan segala ego atas apa yang ia terima sehingga tercipta keadaan jiwa yang penuh dengan kelembutan seperti sabar dan pemaaf. 
Andriyana Fatmawati dan Nur Hanifah Insani/ Piwulang 8 (2) (2020)

h) Ungkêr, pintalan benang tenun. Kumpulan benang yang telah dibersihkan dan siap dipintal menggambarkan kumpulan jiwa yang telah diasah. Jiwa yang awalnya gelap lama-kelaman akan bercahaya seiring dengan bertambahnya ilmu yang dimiliki. Hal ini menunjukkan sebuah perjuangan dan tekad perempuan yang kuat dalam memperoleh kesucian jiwa.

i) Likasan, alat untuk memintal lawe. Semakin bertambahnya ilmu tentunya seorang perempuan akan lebih bijak dalam menentukan tujuan hidupnya. Memilah kehidupan yang lebih bermanfaat atau menuruti ego tanpa mengedepankan syariat. Penekanan syariat Islam pada konteks ini sangat ditonjolkan. Seorang perempuan disamping dituntut untuk tekun menuntut ilmu ia juga diharusnya untuk senantiasa membaca ayat Al Quran dan memantapkan tabiat empat.

j) Sigi, gulungan kapas yang tidak terpakai. Menenun dalam konteks ini dimaknai sebagai kehidupan seorang perempuan dalam berumah tangga. Dalam proses menenun tentunya terdapat banyak kapas yang tidak terpakai sebagai bahan utama untuk membuat benang. Sisa-sisa kapas yang disatukan ini melambangkan pemikiran-pemikiran yang diabaikan ketika dibenturkan pada problematika rumah tangga. Alur pemikiran seorang perempuan ini menentukan sebarapa tinggi ilmu yang dimilikinya dan semampu apa ia menyelesaikan berbagai masalah dalam rumah tangganya.

k) Suri, bagian alat tenun berbentuk sisir besar. Suri melambangkan sebuah jalan untuk menentukan pilihan. Pikiran yang dimiliki seorang perempuan akan menjabarkan berbagai macam pengetahuan sehingga pengetahuan dunia akan semakin jelas terlihat. Seorang perempuan hendaknya berlandaskan iman dalam menjalani kehidupan rumah tangganya. Kekuatan iman inipun diperlukan ketika proses pencarian jati diri sehingga terjaga keseimbangan antara lahir dan batinnya. Seorang perempuan harus mampu mengendalikan pikiran dan ego dalam hatinya agar ikatan pernikahan kokoh dan tidak mudah goyah. Sehingga sebesar apapun permasalahan dalam rumah tangga hendaknya dikembalikan kepada yang Kuasa.

1) Sumbi, bambu yang dililit kapas untuk menarik benang. Ikatan yang kuat pada sumbi ini menggambarkan keajegan dalam melakukan introspeksi diri. Gerakan sumbi ke depan merupakan simbol bahwa manusia akan terus bergerak menuju masa depan. Keseimbangan antara jiwa dan raga akan sangat dibutuhkan untuk menjalankan masa depan yang penuh dengan misteri. Sedangkan gerakan sumbi ke belakang merupakan masa lalu sebagai sebuah sarana untuk perenungan jiwa yang kaya akan hikmah dan pelajaran. 
m) Têropong, tempat dimasukkannya klêting berfungsi untuk melintangkan benang lawe dengan cara bergerak ke arah kanan-kiri secara berulang-ulang. Teropong bergerak ke kiri dan ke kanan secara berulang ulang merupakan gambaran kebahagian seorang perempuan dalam pernikahannya. Gerakan teropong yang konsisten ini mengisyaratkan bahwa sebuah pernikahan juga perlu adanya aktualisasi diri dan penghargaan sehingga tercipta sebuah keharmonisan dalam rumah tangga.

n) Gligèn, kayu berbentuk tabung pada alat tenun. Gligen menyimbolkan suatu sarana untuk memunculkan hasil perenungan diri seorang perempuan. Perenungan ini dapat dijadikan suatu pedoman dalam menentukan jalan hidup yang akan dijalani.

o) Cêlêp, pewarna gelap untuk kain. Celep menggambarkan air kehidupan. Warna kehidupan yang dijalani seorang perempuan tentunya beraneka ragam. Kehidupan manusia seperti halnya warna ada yang gelap ada pula yang terang. Warna gelap menggambarkan kehidupan manusia yang penuh kemungkaran, kebencian dan kebodohan. Sedangkan warna terang menggambarkan keadaan manusia yang berakal serta berilmu sehingga dapat membedakan mana yang baik dan mana yang buruk. Keberanekaragaman warna kehidupan ini tidak luput dari sebuah takdir. Seorang perempuan dalam menjalankan hidup ini berdasarkan ketentuan takdir Tuhan. Sehingga dalam teks Suluk Tenun ini warna terang (purnama) menggambarkan keadaan seorang perempuan yang telah mencapai kesucian jiwa.

p) Walira, kayu untuk memadatkan tenunan. Walira sebagai simbol pemadatan ilmu. Seorang perempuan yang telah selesai menenun artinya sudah mencapai kesuciann jiwa maka akan memperoleh ketetapan iman. Dalam tahap ini seorang perempuan mampu untuk memahami pertanda dari Tuhan, tetapi ketika tandatanda itu tidak terbaca maka tidak perlu berkecil hati. Sesungguhnya dalam hidup ini manusia akan terus berproses dan belajar yang tiada matinya, karena tujuan hidup manusia didunia ini adalah menuntut ilmu.

Citra perempuan yang tertuang dalam metafor-metafor alat tenun diatas merupakan sebuah tahapan hidup yang harus dilalui manusia di dunia demi terciptanya kerukunan rumah tangga. Bekal utama seorang perempuan dalam memulai rumah tangga adalah ilmu pengetahuan. Dengan ilmu pengetahuan maka seorang perempuan akan tahu jalan hidupnya. Selain itu seorang perempuan harus mampu mengendalikan nafsu dalam proses penyucian jiwa. Berbekal niat dan iman yang kuat dalam menyatukan seluruh rasa demi tercapainya ketenangan jiwa. Selalu berusaha terhubung dengan Yang Maha Kuasa serta melibatkan panca indra dalam menangkap dan memahami 
suatu ajaran. Jiwa yang awalnya gelap lamakelaman akan bercahaya seiring dengan bertambahnya ilmu yang dimiliki. Semakin bertambahnya ilmu tentunya seorang perempuan akan lebih bijak dalam menentukan tujuan hidupnya. Mampu menahan ego untuk selalu mengintrospeksi diri akan kesalahankesalahan masa lalu serta bersedia memperbaiki untuk masa depan. Sesungguhnya manusia di dunia ini tidak pernah luput dari kesalahan tetapi manusia akan selalu berada pada tahap belajar hingga akhir hayatnya.

\section{SIMPULAN}

Berdasarkan analisis dan pembahasan disimpulkan hal berikut. Konsep perempuan dalam Suluk Tenun merupakan gambaran perempuan yang ideal pada waktu itu. Perempuan tidak hanya dilihat dari sisi lemahnya saja tetapi perempuan mempunyai peranan penting dalam membangun rumah tangga. Dalam teks Suluk Tenun dijelaskan beberapa citra yang harus dimiliki oleh seorang perempuan agar mampu menjadi perempuan suci. Citra tersebut adalah: (1) perempuan harus berilmu, (2) perempuan harus mampu mengendalikan hawa nafsu, dan (3) perempuan harus bersandar dengan iman kepada Tuhan serta syariat.

\section{DAFTAR PUSTAKA}

Andrianie, Kurnia. (2004). Konsep Pernikahan dalam Serat Piwulang Estri. Skripsi S1 Prodi Sastra Jawa FIB UGM.
Chalil, Moenawar. (1977). Nilai Wanita. Solo: C.V. Ramadhani.

Mulyanto. (2018). Panduan Pendirian Usaha Tenun Tradisional. Jakarta: Badan Ekonomi Kreatif

Sugihastuti. (2000). Wanita Di Mata Wanita: Perspektif Sajak-Sajak Toeti Heraty. Bandung: Penerbit Nuansa.

Widyastuti, Sri Harti. (2001). Suluk Wujil Suntingan Teks dan Tinjauan Semiotik. Semarang: Kelompok Studi Mekar - (2014). Kepribadian Wanita Jawa dalam Serat Suluk Residriya dan Serat Wulang Putri Karya Paku Buwono IX. Litera, Volume 13, Nomor 1, April 2014, 114-127.

Wulandari, Arsanti. (2016). Piwulang Estri Sebagai Bentuk Reportase Tentang Wanita Jawa. Manuskripta, Vol. 6, No. 2, 2016, 1-17.

Wuryani, Sri. (2013). Lurik dan Fungsinya di Masa Lalu. Ornamen, Volume 10, Nomor 1, Januari 2010, 81-99. 